\title{
O CORPO ENCONTRA APOLO E DIONÍSIO: POTÊNCIAS E FRAGILIDADES
}

\section{Vilene Moehlecke Tania Mara Galli Fonseca}

\begin{abstract}
Resumo: Pretendemos problematizar o corpo que não agüenta mais e suas relações com a estética. Primeiramente, pensamos a dimensão apolíneo-dionisíaca da Arte, como refere Nietzsche. Assim, Apolo nos remete às belas formas, à técnica na dança, enquanto Dionísio significa a embriaguez, os riscos e as intensidades. A dança contemporânea se faz a partir do entrelaçamento entre ambos, potencializando os paradoxos do corpo. Nesse sentido, não agüentar mais exprime uma potência do corpo, uma capacidade de não agüentar mais as velhas formas e produzir novas alterações. Ítalo Calvino pensa a literatura como composição de novas expressividades. Então, o corpo que escreve pode não agüentar mais as velhas palavras para criar novos sentidos e novas linguagens. Por fim, discutimos o quanto as práticas psi estão buscando não agüentar mais as próprias durezas, as antigas verdades, os mesmos fazeres, para compor novas intervenções e novos conhecimentos.
\end{abstract}

Palavras-chave: Corpo. Arte. Estética. Conhecimento.

A Arte pode se tornar uma possibilidade consistente de transformação, uma vez que ela ativa uma diluição de antigas certezas e provoca uma construção de novas territorialidades. $O$ paradigma estético nos faz pensar que a vida está em movimento e que temos a chance de romper com aquilo que nos aprisiona, em direção ao intempestivo e à diferenciação. Ao invés de priorizarmos verdades ou clichês, podemos pensar na valorização daquilo que excede e ultrapassa nossos atuais modos de ser. Podemos desnaturalizar aquilo que parecia natural ou estável e provocar novos questionamentos no cotidiano. Assim, quando estamos dispostos a refletir sobre 
nossas práticas, temos a chance de traçar conexões entre a Arte e outros saberes, na tentativa de agenciarmos outras plasticidades para os nossos modos de relação com o mundo e com o conhecimento. $O$ processo de cognição pode estimular a construção de novas linguagens, ao romper com a lógica de um mero reconhecimento daquilo que já se sabe e propor a maquinação de novos sentidos.

Nesse ponto, acionar o artista, em nós, requer um movimento de desprendimento de antigos valores, e promove uma busca por novas contaminações com aquilo que difere. Isso implica, também, numa postura ética, de abertura frente à vida, a fim aceitar o que ela pode nos oferecer, seja alegria, desprendimento, dor, gozo ou diferença. Com isso, propor um mergulho na experiência estética implica exprimir-se de múltiplas maneiras, ao transitarmos entre a beleza de Apolo e a intempestividade de Dionísio. Para Nietzsche (1888/1995), Dionísio pode dizer sim à vida, e tem, em si, o eterno prazer no destruir. A isso o autor chamou de poeta trágico, ou seja, aquele que investe no processo de vir a ser, para compor a singularidade de sua expressão. A tragicidade requer, pois, um plano de complexidades, em que o artista, ou o sujeito, se deixa afetar pelas intensidades da vida, sejam elas de realização ou tristeza, de desejo ou insensatez.

Do mesmo modo, o corpo é capaz de suportar novos encontros com o plano estético, com o intuito de torná-lo mais poroso, mais atento aos mistérios que o cerca. $O$ sujeito pode se deixar afetar pela vertigem do inesperado, que o lança para novos arranjos e ritmos. Com isso, não debruçamos o nosso olhar sobre a forma que se repete ou que se mantém, mas sobre a possibilidade do desmanche e do acionamento de novas virtualidades. Assim, a literatura e a dança contemporânea podem convidar o corpo e as palavras a experimentarem novos gestos e a se deliciarem com tais riscos. Se o artista se cansa do seu contorno, ele tem a potência de buscar a própria superação. $\mathrm{Ou}$, caso ele não suporte mais a própria configuração, o que é possível fazer, ou tentar, na busca de uma experiência estética do si?

Nesse trabalho, pretendemos refletir sobre o corpo que dança, e também sobre o corpo que escreve, na tentativa de produzirmos algumas articulações entre o corpo, a estética e a produção de conhecimento. Temos a possibilidade de compor um encontro entre a Psicologia e o plano estético, para construirmos novos diálogos entre ambos e pensarmos os efeitos dessa conexão. Desse modo, estamos dispostos a articular um plano conceitual, para tecermos uma trama entre a dança, a literatura, o corpo e a produção de conhecimento em Psicologia.

\section{Dançando com o corpo e suas facetas}

Um corpo se arrisca ao dançar. Ele treme ao sentir o inesperado do seu movimento. E, no momento em que transita entre os próprios limites 
e as possibilidades de transbordamento, ele chama o público, num convite a percorrer o olhar que os liga a um plano de composição e abertura. $\mathrm{O}$ artista percorre caminhos sinuosos e melodias inéditas, ao se lançar num mundo de novas virtualidades e de conexões singulares. Assim, ele dança e se encontra com as intensidades da vida, uma vez que formula a vibração que o transporta para novos sonhos. Ao se deixar afetar por aquilo que o transforma, o corpo se torna bailarino e passa a experimentar as dores e os gozos de sua diferenciação.

Nesse sentido, não tomamos a noção de identidade ou de permanência, para não cairmos na ilusão de pensarmos o corpo como coisificado ou substanciado, que encontraria na vida apenas a sua evolução. Ainda, não queremos dividi-lo, em mente e corpo, alma e carne, como se o enxergássemos por meio de uma lógica segregadora e dualista. Portanto, tentamos complexificar o corpo, ao procurarmos mapear os seus paradoxos, suas coexistências e o seu potencial de dissolução. Assim, não somos um corpo, tampouco o possuímos, mas estamos envoltos num movimento intensivo e sutil de viver a sua experimentação e o seu desdobramento. Ao invés de conservação, ele luta para tornar-se digno daquilo que é, ou que pode se tornar, com o intuito de saborear os seus limites e os modos de ultrapassagem da atual composição.

Deleuze e Guattari (1996), para problematizar a diferença do corpo, abordam a questão do corpo sem órgãos e fazem referência a Artaud. Podemos, portanto, refletir sobre tais idéias e buscar uma relação com o corpo e o dançar. Assim, o corpo sem órgãos é matéria intensa e não formada, não estratificada, uma intensidade igual a zero, em que não há nada de negativo. Ou seja, o zero favorece a produção de vazios, de espaços incompletos, de vácuos de sentido, de mistérios intensivos, que podem ser preenchidos de modos diversos, isto é, através de múltiplas ações do corpo. Pode ser interessante, portanto, ocupar o vazio de jeitos variados e favorecer o encontro de muitos elementos, além de incitar a formação de um bloco de devir que irradia deles. Isso pode propiciar um desmembramento de antigos contornos e, simultaneamente, tornar possível a composição de novos vazios e instabilidades.

O corpo sem órgãos, ao se tornar intenso e igual a zero, permite sua abertura a novas composições e a conexão do ser ao caos, num jogo imprevisível, que se faz e desfaz, e o leva a acontecer de muitos modos. Isso quer dizer que ao invés de um corpo pleno, bem definido, repleto de segurança, trata-se de um corpo esvaziado, esburacado, roubado de suas certezas, maleável e escorregadio. Ou seja, o vazio é entendido como potência de variação. $O$ corpo se esvazia e se entrelaça a atmosferas diversas, a fim de se tornar capaz de absorver novas linguagens, de encontrar novos elementos, além de sentir sabores variados. Na dança, e também na vida, pratica-se o desejar e o não desejar, a forma e a sua dissolução, numa tentativa de deixar-se ir, de abandonar o corpo atual e sua organização, ao almejar 
novas práticas e modos estéticos de existir. O ser, ou o bailarino, ao tentar criar um corpo sem órgãos, torna-se vazio e também cheio de intensidades circulantes, dentre velocidades e lentidões, através de movimentos sinuosos e raros. Rompemos, pois, com o corpo identitário e pensamos o corpo intensivo, que se arrisca a dançar.

Segundo Gil (2002), o corpo dançante existe na abertura permanente ao mundo, por meio do silêncio e da não-inscrição. $O$ bailarino pode ser desertado, esvaziado, roubado da sua alma, ao se deixar atravessar por fluxos exuberantes da vida. E, assim, o corpo experimenta os seus paradoxos e convive com a imprevisibilidade da sua potência de criação. Ele pode, a qualquer momento, se tornar um novo gesto estético. Ele deixa para trás antigas limitações e aposta na força daquilo que pode se tornar.

O corpo intensivo se torna dançante, pois ele se desprende da própria organicidade e trabalha para uma nova configuração. Ele não está pleno, mas tornado deserto, vazio de significados e certezas, já que ele deseja o entrelaçamento com o cosmos. Com isso, o artista sai de si e experimenta uma nova conexão, que o lança para a dramaticidade de sua prática.

Assim, pensamos a arte enquanto beleza, mas também como um jogo complexo de arrebatamento e contrastes. Nietzsche (1872/1992) pensa a questão da Arte, a partir dos deuses gregos, Apolo e Dionísio. Esse filósofo discorre sobre o prazer no destruir, que é próprio do estado dionisíaco, isto é, trata-se de embriaguez e paixão, volúpia e gozo, coragem e dor, ou seja, intensidades circulantes. Na tragédia, é fundamental amar a destruição, para que, a partir dela, possam surgir novas formas e novos enredos. Dessa maneira, o corpo se torna outro e incita a maquinação de novas linguagens, já que ele busca a singularidade possível em cada ato de expressão.

Além de Dionísio, Nietzsche (1872/1992) salienta a dimensão apolínea da Arte, isto é, as belas formas, a leveza, os contornos bem definidos, a clareza e a desenvoltura. Assim, a Estética se constitui a partir dessas duas dimensões simultâneas: a forma e o informe, a embriaguez dionisíaca misturada com a bela forma apolínea. Os riscos de Dionísio misturados com os limites definidos de Apolo, eis o caráter paradoxal da Arte. Vivenciar o trâmite entre as definições da obra e a ultrapassagem de si implica a complexidade da experiência estética, o que leva o artista a mergulhar numa trama de novas simulações e aventuras.

$\mathrm{Na}$ dança contemporânea, também podemos visualizar uma Arte apolíneo-dionisíaca, visto que visualizamos um corpo que busca riscos e certezas, ou potencialidades e limites. Isto é, primeiro, o corpo aprende e aprimora a técnica da dança, que não é nada fácil e exige muitos anos de dedicação do bailarino. $O$ corpo que dança aprende a se tornar belo e a produzir seus gestos e movimentos com suavidade e precisão. Depois, ele começa a querer a destruição da forma, para criar o informe. Quando o gesto estético acontece, Apolo e Dionísio se encontram, e provocam um esta- 
do de meta-estabilidade, uma vez que o entrelaçamento de seus avessos pode incitar a coexistência entre a definição do contorno e a provocação do seu desmanche. Após anos de ensaios e aprimoramentos do equilíbrio e da técnica, o corpo que dança encontra Dionísio para desequilibrar, para encontrar o avesso da técnica, o contrário da certeza, criando o próprio estranho no movimento.

Segundo Gil (2001), o bailarino é capaz de perder o seu equilíbrio e se arriscar a cair no vazio. $O$ artista busca, no movimento, uma pequena estabilidade para a sua extrema agitação interior. Ele espera ocupar um novo espaço, efêmero, por cima do abismo, que o coloca numa nova relação com aquilo que o invade. E, ao transitar entre as forças instáveis que o convocam a uma nova ruptura, o corpo que dança compõe um elo estético entre o mundo e suas perplexidades.

Assim, o corpo se afeta pelo dançar, equilibra e desequilibra, invade novos espaços intensivos. Ele se faz a partir de Apolo e Dionísio, entrelaçados, simultaneamente, brincando e trabalhando com as possibilidades e os paradoxos do corpo. Se o corpo amasse somente a destruição, o informe, ele não dançaria, não seria capaz de compor as imagens e as criações que brotam de sua matéria, sua carne. O bailarino não seria capaz de politizá-lo, não conseguiria expressar as intensidades do mundo, de uma forma bela e sutil. Sem Apolo, o corpo que dança não alcançaria a sua suavidade para falar de questões variadas, sejam elas amenidades, tragicidades ou uma simples estória a ser narrada por quem faz do movimento e do som a sua forma de expressão. Sem a técnica da dança, o corpo também se move, mas é apenas capaz de criar gestos grotescos, impensados, estranhos. A técnica se faz necessária, para explorarmos a potência do corpo, buscando seus segredos, suas estórias, suas comédias e suas durezas. $O$ belo é importante para que se faça Arte, e para que dele se possa transcender, ir além. Ele revela a qualidade do movimento, a definição das ações, e traz os limites do corpo.

Por outro lado, se ficássemos apenas em Apolo, estaríamos somente no plano do controle sobre os corpos, na técnica puramente pela técnica, no ensaio-erro, na dimensão matemática da dança. Não estaríamos, então, numa dimensão estética, que prima pela plasticidade e pelo transbordamento. $O$ corpo que se contenta com as belas formas, com sua própria beleza, não consegue criar paradoxos, uma vez que evita que a potência do novo se faça presente em seu espaço. No momento em que o bailarino experimenta a própria tensão e o esburacamento de si, ele tem a potência de se envolver numa trama de novas possibilidades e pode sentir a força de diluição de seus modelos anteriores. Isso o toma e o lança para uma nova composição do movimento.

Gil (2002) argumenta que, quando nos grudamos num certo corpo identitário, seja um corpo obcecado por belas formas apolíneas ou um corpo capturado pela sociedade de consumo, ou qualquer outra forma que se cristaliza, então já estamos na desgraça dos corpos. O corpo belo, e as- 
sim condizente, pode acabar sendo capturado pelo sistema, que também preza somente as formas apolíneas e os clichês. Nesse caso, não amamos a destruição, mas, sim, a manutenção do mesmo contorno. No momento em que estamos em plena posse desse único corpo, então ficamos condenados a habitá-lo e dele não conseguimos nos livrar tão facilmente. Se, paradoxalmente, o corpo é feito para desaparecer, sua atualidade é sempre móvel. Assim, o corpo existe mais quando não existe, pois ele sente o sentido do mundo vibrar em suas expressividades. Ou seja, o corpo encontra a sua potência, quando se permite escorrer dos seus limites e se jogar num turbilhão de novas acessibilidades. Isso o torna mais dionisíaco e conectado com a insensatez daquilo que está fora de si, mas ligado aos seus acasos e descobertas estranhas.

Ora, de outro modo, se o artista fica aprisionado em sua forma atual, ele apenas luta para a sua manutenção e espera diminuir o acesso a suas tragicidades e forças. Em meio a esse controle sobre si, o corpo não agüenta mais Como argumenta Lapoujade (2002), isso significa dizer que, por um lado, existe um controle sobre os variados corpos que habitam nossa contemporaneidade, por meio da exigência de belas formas, do consumo desenfreado, ou do gozo do entretenimento constante; e, por outro lado, sempre existem forças de resistência, já que é possível encontrarmos alternativas para esburacar a lógica do aprisionamento e das homogeinizações. E, ao buscar conexões com a vontade de ir além do clichê, o sujeito deseja a ampliação da potência do corpo. Nesse aspecto, não agüentar mais não quer dizer não resistir por muito tempo, uma vez que esse movimento impele o corpo a buscar novas intensidades e a questionar as formas atuais. O sujeito passa a não suportar mais a repetição e cria uma resistência dotada de um profundo fortalecimento, que resiste às formas de coerção e massificação vigentes. Ao não agüentar mais as próprias composições, o corpo exprime seus modos de resistência frente àquilo que o oprime ou o assujeita. E ele passa a desejar o seu transbordamento.

Assim, o corpo não agüenta mais as velhas formas, os controles e a padronização das condutas. O corpo não suporta mais seu próprio contorno, pois já está pedindo passagem para uma nova resolução, com novas forças e outras intensidades. O corpo atlético, à procura de Apolo, não agüenta mais desejar apenas o músculo e a repetição, mas ele também quer algo mais, quer ultrapassar a si mesmo, quer querer outras coisas, para além da academia de ginástica. $O$ corpo consumidor, da mesma forma, não agüenta mais querer o consumo, quer consumir outros valores, outros sentidos, outras formas, e não apenas a coisa que compra no shopping center. Ele quer consumir a vida, o trágico, o acaso das ruas. $O$ corpo não agüenta mais querer unicamente a sedução, a aceleração e a instabilidade, ele quer também a luz, a pausa, o encontro intenso com outros corpos, as afecções, a composição de novos agenciamentos, a procura por novos lugares, por outros valores, para além do próprio gozo. 
Nesse sentido, o corpo que dança pode não agüentar mais sua técnica, seu próprio controle ou seu contorno definido. Ele pode se lançar no acaso de novos gestos e de novas composições corporais, que diluam os parâmetros do correto e da boa forma. O bailarino pode não agüentar mais seu encontro com Apolo para que, a partir daí, ele encontre Dionísio. Do mesmo modo, ele tem a chance de não agüentar mais Dionísio para que Apolo possa ressurgir com sua força. Assim, há um jogo constante de forças, num movimento de transmutação do que o corpo busca ao dançar. Ele sente os ritmos frenéticos do limite e da diferenciação, quando vivencia as complexidades da experiência estética.

O corpo, ao dançar, potencializa e traduz os afetos ali impregnados, sejam os seus ou dos demais criadores. Coreógrafos e bailarinos podem, pois, produzir uma comunicação e uma sintonia fina, para alcançar a realização dos movimentos dançados, uma co-criação. Na dança contemporânea, um gesto dá caminho ao outro, um movimento pede passagem ao seguinte. Não se sabe até onde vai um e onde começa o outro. Eles se conectam, se misturam, delineando uma harmonia no corpo que dança. $\mathrm{E}$, para que haja a mistura de gestos, o corpo pode não agüentar mais, ele tem a possibilidade de desaprender o que tem sido, para se tornar outro. Ele não suporta a individualidade, e deseja o encontro com aquele que difere e produz novos ritmos.

Com isso, o corpo do bailarino se permite impregnar por novos movimentos, diversos ritmos e outras linguagens coreográficas. Ele passa a compor o seu universo artístico e a transformar a própria expressão. Gil (2001) diz que o movimento dançado cria o espaço dos duplos, das multiplicidades dos corpos e dos movimentos corporais. O bailarino não agüenta mais o próprio gesto, ele quer experimentar os encontros com outras materialidades e melodias. Ele pode fazer do seu corpo uma multiplicidade, uma extensão para outras intensidades e forças que compõem a vida.

Além disso, o corpo dançante não deseja unicamente o gozo, ele pode se confrontar com a dor. Atualmente, temos dificuldades para lidar com o sofrimento. Ou o transformamos em doença ou nos tornamos insensíveis, quase que anestesiados. Essa última saída seria o que os modos, homogeneizados e homogeneizantes de nossa atualidade, preferem, isto é, a ilusão de uma imunidade à dor. Na realidade, as duas saídas caminhariam juntas. Essa rejeição ao sofrer é, talvez, o que o corpo não agüenta mais. Isso o conecta a uma vida trágica, quando saboreia suas conquistas e respeita as dores dos seus fracassos. $O$ corpo pode esgotar as alternativas de resolução frente ao mundo.

Segundo Deleuze (1996), o esgotamento é algo mais intenso do que o cansaço. Esse último funciona como um esgotamento da realização, ou seja, o cansaço abarca o possível e surge da realização excessiva de uma possibilidade. Desse modo, alguém se cansa devido ao número excessivo de vezes que executa uma operação. $O$ esgotamento, contudo, abarca algo 
mais complexo. O sujeito esgota todo o possível, vai além do limite de suas tendências e pode esgotar com o espaço e a imagem. Isso significa extenuar a possibilidade e converter em impossível todo o encontro. É interessante, para tal prática, um contato, ou uma conexão, talvez uma quebra advinda de um desvio, ou característica de um hiato, semelhante ao resultado de um pequeno salto que prevê o encontro e o devir.

Cabe lembrar, porém, que não se trata de realizar o impossível, mas de esgotar o possível, e, a partir daí, compor outras realidades, mais avessas ao padrão. Para isso, podemos experimentar o desequilíbrio, tecer novas tramas, trabalhar para o estranhamento do gesto, ou, ainda, deslizar por sua insensatez. Ao dançar, o corpo pode se cansar, uma vez que ele realiza, muitas vezes, uma única possibilidade, e tenta buscar o aprimoramento e a qualidade do mover. Nesse caso, o bailarino sente as dores dessa tentativa, ao sofrer o peso da repetição, pois ele sabe a importância de sua técnica e do seu mover coreográfico. A repetição, nesse caso, também faz parte de suas práticas.

O corpo, contudo, para dançar com paixão e complexidade, deseja vivenciar o seu esgotamento. Nesse caso, ele experiencia, até o limite, várias possibilidades, pois almeja esgotá-las e, a partir daí, criar outras configurações. Ele pode investir nos contágios com a vida, na tentativa de expandir os elos que os unem, para, assim, estabelecer novas relações e provocar outras sinuosidades. $O$ corpo esgotado pode se tornar, pois, um modo de experimentação criativa de existir, por meio de um jeito variado de acontecer esteticamente. $\mathrm{O}$ bailarino, portanto, compõe-se enquanto um corpo cansado e, também, esgotado, já que ele transita entre os paradoxos da repetição e do ultrapassamento de si. Assim, entre prazeres e dores, ele pode experimentar e saborear a intensidade do movimento recriado, ou seja, ele vive o gosto do acontecimento estético. $O$ esgotamento combina o conjunto de variáveis de uma situação à condição de renunciar a toda ordem de preferência e a toda organização de metas, isso é, a todo o significado. $O$ corpo esgotado, ao abdicar das certezas, pode procurar vazios e silêncios, brechas da razão, e abrir mão de buscar os significados já conhecidos, nas palavras ou gestos.

Lapoujade (2002) argumenta, então, que o sofrer é a condição primeira do corpo; é estar exposto ao fora. O corpo que sofre é o corpo que é afetado pelo fora, um corpo que não cessa de se abrir aos encontros com outros estranhos, com a luz, com o oxigênio, com os alimentos, com as palavras etc. Porém, uma total exposição ao fora é insuportável, mesmo que o corpo precise viver um pouco desse insuportável, criando, para si, um Corpo Sem Órgãos. Desse modo, é possível se defender das feridas mais grosseiras e abrir-se às feridas mais sutis. Tratar-se-ia de resistência. De um lado, o corpo não agüenta mais e pode se defender daquilo que é mais grosseiro e o faz sofrer; de outro lado, o corpo se afeta e se abre a tudo o que advém sob o regime do sutil. $O$ corpo pode se fechar para se abrir. 
O corpo do bailarino, nesse ponto, não agüenta mais uma total exposição ao Fora. E, ao mesmo tempo, ele é capaz de se abrir às forças sutis, às intensidades que produzem seus movimentos, que geram sua energia e seus novos contornos. Ele se abre à música que conduz sua dança, no momento em que a energia flui por seu corpo. Novas vibrações são vivenciadas, e o espaço do palco se expande em outras conexões. $O$ bailarino se expõe ao calor do público, às intensidades da coreografia e da atmosfera que compõem o espetáculo.

Nesse sentido, poderíamos levantar a questão: o que acontece quando um bailarino entrega seu corpo às forças do Fora, que o fazem girar rapidamente, com extrema leveza e desenvoltura? Há vários pontos a serem observados para que o giro aconteça: o impulso deve ser dado na medida certa; é preciso manter-se sob a ponta dos pés, não dobrar o joelho de base, manter as costas alongadas; os braços devem estar numa posição correta, mas o mais importante não está aí. Sabemos que o princípio para que o bailarino execute seu giro com eficiência e equilíbrio está na sua cabeça: ela é a última que sai e a primeira que retorna. O que decorre daí? É como se a cabeça fosse a responsável pelo caráter sutil do movimento. Todo o corpo não agüenta mais e se joga às forças do Fora, sentindo os impulsos frenéticos que faz o corpo inteiro girar numa velocidade inexplicável. Entretanto, a cabeça se mantém o máximo de tempo possível no mesmo lugar, até não agüentar mais, como se ela ainda mantivesse a resistência de não abrir todo o corpo ao Fora.

Isso faz com que a abertura se dê num regime sutil: o corpo se abre, mas mantém seu eixo, permitindo apenas que algo sutil, quase imperceptível, penetre no corpo que gira. Depois, a cabeça se joga, mas, tão rapidamente, que ela retorna antes do corpo. O corpo todo esteve no Fora, mas procurou seu eixo, fazendo sua dobra; pois, ao voltar, o bailarino já é outro.

Assim, quando o corpo do bailarino não agüenta mais e passa a se abrir às forças sutis, ocorre aí uma intensificação da potência do corpo e uma preparação para que múltiplos corpos advenham deste primeiro. Isso supõe um caráter paradoxal do próprio corpo. Não agüentar mais é, pois, uma força de resistência e uma condição fundamental, a favor dos paradoxos do corpo que dança.

Nesse sentido, não agüentar mais pode significar um movimento de saúde. $O$ corpo que dança está constantemente tentando ativar essa potência, a fim de promover o encontro entre Apolo e Dionísio, com o intuito de ampliar suas potências, possibilitando um além do eu individual, psicológico. O corpo, no contemporâneo, carrega as marcas de um controle que promove os imperativos da era de Apolo, a favor das boas formas e da noção de uma identidade definida, eis o seu aprisionamento. Ao mesmo tempo, porém, o corpo desde sempre não agüentou mais. Então, desde sempre ele questionou esse aprisionamento, ele não se conformou com o controle, com os limites que lhe foram impostos pela sociedade de consu- 
mo. A dança contemporânea pode ser uma das alternativas possíveis, mas não a única, para o não agüentar mais do corpo.

\section{A dança das palavras}

Quando estamos diante da folha branca, ou em frente ao computador, por alguns instantes, nos deparamos com o vazio de sentido. Pouco a pouco, somos tomados por um ímpeto de compor algumas expressividades com a palavra. Assim, o sentido nos atravessa e, ao mesmo tempo, somos produzidos por aquilo que inventamos. Fazemos história e nos tornamos parte dela, ao conduzirmos nosso dizer para direções variadas. E esse processo nos faz transitar entre o que sabemos e o que podemos construir. Ora, dizer o que já sabemos não compõe uma nova trama, apenas retoma o significado já conhecido. Nosso movimento traz a força de nossa ignorância, uma vez que aprendemos que as verdades são transitórias e efêmeras e podem, a toda a hora, desfalecer.

Escrevemos sobre aquilo que não sabemos, mas que, de algum modo, percorre o nosso corpo e deixa sua marca. Mais do que formas, somos tomados por forças, que nos impulsionam para novas palavras. Nesse sentido, escrever é devir, uma vez que se trata da potência do informe, daquilo que podemos nos tornar. Segundo Deleuze e Guattari (1997), esse processo não requer imitação ou seguimento de um modelo, tampouco se caracteriza a partir de semelhanças ou atos de identificação. Tal conceito não se refere a questões de parentesco ou a relações formais. Ainda, não quer dizer regredir ou evoluir. Antes disso, o devir requer um ato de involução, pois implica a dissolução da forma, a quebra das certezas e a ruptura dos modelos, para que novas imagens sejam possíveis e outros contornos sejam criados. Ou seja, o vir a ser demanda invenção e formação de um bloco singular, entre os termos heterogêneos, que se cruzam e divergem. Assim, com o intuito de criar uma nova linha, os elementos podem se misturar e provocar uma espécie de simbiose e contágio, onde novas forças e formas são agenciadas.

Assim, temos a possibilidade de aprender, ao deixarmos que os mistérios nos invadam e entrem em contato com a nossa suposta ilusão de verdade. Isso nos leva a romper com as seqüências já definidas, ou a tentar esburacar aquilo que parecia ter um sentido único. Por outro lado, ao abrirmos mão de nossos saberes anteriores, temos a chance de iniciar uma nova escrita, e povoá-la de significados movediços e intensivos. Deixamos que as sensações nos contaminem, quando compomos novas melodias para aquilo que desejamos exprimir. Desse modo, escrevemos com o corpo, com a sensibilidade, com o desejo de não retornar aos velhos significados, na tentativa de configurar uma nova paisagem com aquilo que nos desarma e nos impulsiona para novas afecções. A mão escreve, ou digita, 
mas leva também o corpo todo, ou parte dele, pois retoma a angústia de olhar para aquilo que não tem um contorno definido, e passa a tecer uma territorialidade escrita para isso que a absorve. Não há mais como suportar uma palavra que somente comporta o que já sabemos.

Portanto, o corpo que escreve, desde sempre, está esgotado, não agüenta mais. Ao construirmos a escrita, podemos esgotá-la em muitas das suas possibilidades, experimentá-la de múltiplos jeitos. O corpo que escreve pode não agüentar mais os velhos contornos, as mesmas palavras, o estilo corriqueiro, para, a partir daí, compor um novo universo de linguagem e expressão. Pensamos que a escrita pode ser olhada como um dispositivo do corpo que não agüenta mais e que quer querer outra coisa, outro corpo. E, na tentativa de problematizá-la e de arrancá-la de um lugar comum e conhecido, podemos romper as amarras com a representação e relançar o texto num emaranhado de fluxos e de significados nômades, que o jogam para uma trama de mensagens e interpretações, sempre sujeitas a novas demandas e a outros vínculos.

$\mathrm{E}$, se o corpo não agüenta mais as velhas formas, como ele pode acionar outros contornos para a sua linguagem? Ou, se a escrita está esgotada, de que modo é possível compor novas expressividades com a palavra? Em nossa tentativa de buscar subsídios na Arte, encontramos a Literatura.Tentamos, com ela, rachar as palavras, no meio, a fim de que a tomemos em seu propósito de dilatação e contágio com o cotidiano. Na literatura, podemos encontrar uma fala mais plástica, envolvente e aberta a novas significações. Calvino (1990) discorre sobre mecanismos fundamentais para a criação, entre eles está a exatidão.

Desse modo, cabe a questão: o que o escritor deseja, ao compor uma exatidão em seus gestos escritos? Segundo Calvino (1990), há, atualmente, uma perda da expressão lingüística, uma diluição dos significados e um embotamento dos pontos expressivos, extinguindo-se, assim, toda centeIha que crepite no encontro das palavras com novas circunstâncias. Isso está presente não só na Literatura, mas, também, na vida, como um vírus que a ataca, tornando-a inexpressiva e fraca de sentidos. Ora, não percebemos, também, um embotamento da existência, quando formas de ser se grudam em modos atléticos ou consumidores em nossa atualidade? Nesse sentido, a Arte, seja a dança contemporânea ou a literatura, dentre outras, consistem numa forma de opor-se a essa inexpressividade, procurando compor uma nova força ao valor da exatidão, que Calvino discute em seus três aspectos principais: um projeto de obra definido; evocação de imagens visuais nítidas; e uma linguagem precisa, capaz de traduzir as sinuosidades do pensamento e da imaginação.

Então, o corpo que escreve pode não agüentar mais o embotamento da vida e da linguagem, para poder criar novas palavras e idéias, usando do recurso da exatidão para traduzir as sinuosidades do que pensa e imagina. Tal tradução não implica uma simples transposição de linguagens, 
mas busca uma composição de encontros entre o que se imagina e o que se expressa, seja pela palavra ou pelos enredos criados. Trata-se de uma língua menor, uma gagueira, que se abre às virtualidades da palavra e percorre múltiplas possibilidades de sentido. Assim, na literatura, a exatidão se torna uma estratégia de resistência contra o corpo perante o mundo. Ela requer uma busca por expressão, contágio, destreza, cor, sentido, vida. Esse mecanismo não se limita a formar uma identidade, seja o movimento dado à palavra. Ao contrário, a exatidão entende o corpo como uma entidade débil, que pode não agüentar mais a qualquer momento, desandando em outro corpo, outro gesto, outra linguagem, outro enredo.

Nesse ponto, nos questionamos se a produção textual, na produção de conhecimento, também não pode promover encontros com a literatura, no sentido de aprender com a experiência estética as suas artimanhas e seus movimentos intensivos. Os saberes acadêmicos, nesse caso, também podem se tornar mais maleáveis, no sentido de procurar processos estéticos em sua movimentação escrita. $O$ sujeito tem a possibilidade de se deixar afetar por aquilo que escreve quando ele se permite viver o encontro com o inesperado de suas reflexões. Pesquisar, nesse sentido, não requer a descoberta de um saber, mas implica uma relação ontológica do sujeito com o mundo que, segundo Kastrup (2007), nos insere em uma política construtivista da cognição. Ou seja, não pensamos o mundo como algo dado a ser apenas descoberto, mas entendemos que o processo de aprendizagem se dá pela invenção e pela resolução de possíveis embates. Aprender, nesse caso, requer a construção de novas problemáticas e a composição de uma escrita irriquieta e envolvente, implicada com o tema a ser discutido. Nesse sentido, a pesquisa tem uma relação direta com o estilo do texto, que incita a composição de novos rumos para aquilo a que queremos dar sentidos. Temos a chance de romper as palavras, pelo meio, a fim de compor uma pesquisa mais criativa, sensível aos acasos que rondam nosso dia-a-dia.

E, apesar dos seus dramas e das suas dores, a vida pode saltar no encontro das palavras, ao tornar possível a conexão entre o belo e o insensato. Escrever pode se tornar, então, um movimento ético e estético, que prima pelo esburacamento dos significados e ama a própria destruição. Permeamos Apolo, na beleza do que é dito, nos limites definidos e claros e, paralelamente, escorregamos na ousadia de Dionísio, no momento em que somos atravessados pelos riscos e voluptuosidades atravessadas no ato da escrita. As palavras jogadas no papel primam pelas suas complexidades, quando suportam o encontro paradoxal de Apolo e Dionísio. Se, por um lado, a técnica é fundamental, já que ela traz a primazia da gramática, da lapidação do sentido, além do embasamento do conceito, por outro, o gesto estranho da frase vai servir como propulsor para novos desprendimentos e outras argumentações. 
Envolto em tais inquietações, o corpo que escreve pode percorrer as variações de forma e de tonalidade para aquilo que ele tenta dizer. Ele não tem controle sobre suas ações, o que vai garantir a riqueza e a alteridade de sua expressão. Nesse ponto, podemos compor uma nova melodia para as palavras, envoltas numa nova gramática e num outro estilo para seus embates. Se o corpo que escreve não agüenta mais, ele pode se arriscar a compor novos gestos, pode tentar dançar no ritmo de suas variações e descobertas. Ele se abre ao caos e, a partir desse encontro, vive novas aberturas e possibilita a construção de uma linguagem mais plástica, envolta de um não saber e de uma nova gama de sensações e afetos.

Nos embalos das frases, o corpo tem a potência de desmanchar a escrita atual e produzir a maquinação de novas falas, transitórias e móveis, que carregam, em si, o gosto pela diferenciação. Saímos da imobilidade e podemos entrar num terreno cheio de irregularidades, que convidam o texto a saltar e a aprender com suas fissuras. Promove, pois, piruetas com as dicotomias, ao buscar a multiplicação de sentidos e a inversão de valores e hierarquizações. Saltamos de um ponto a outro, para criar novos gestos com as palavras e deixar que os vazios nos tomem e nos levem para outras sensações. Ao invés de certezas, procuramos uma ação que se depreende em elementos heterogêneos, comporta a imprevisibilidade da vida e ama a combinação que pode surgir de tal encontro.

Portanto, a escrita também devém bailarina, quando se deixa levar pela vertigem e pelo arrombamento do acaso, provenientes dos contágios com a vida. A palavra dança e se inventa, pois permite o roubo de si e a entrega ao mundo. Ao se envolver com estranhos, o texto tem a chance de sonhar e de compor um novo passo para o seu desejo. E, numa melodia sinuosa e cheia de contrastes, o corpo que escreve pode encontrar o seu avesso e trabalhar para a sua alteridade, já que ele não agüenta mais a própria desolação.

\section{Novos ritmos para a Psicologia}

Propomos uma composição de novos enredos para os saberes em saúde, com o intuito de pulverizar o campo de conhecimento e ampliar as práticas possíveis. A Psicologia, nesse sentido, constitui-se como um paradigma ético e estético de maquinação de novos modos de ser, para além da doença ou da vitimização do sujeito. Ela se compõe enquanto construção de novas problemáticas e novas alternativas para a pesquisa. $O$ corpo que intervém tem a possibilidade de questionar as suas maneiras de pensar e os seus modos de agir, a fim de criar novos dispositivos de trabalho. Assim, podemos dilatar as discussões sobre o corpo psi, a fim de torná-lo mais móvel, estrangeiro de si, ou mais disposto a experimentar o gozo do estranho que o acomete. Isso implica uma tentativa de tornar o gesto psi 
mais intensivo, mais aberto aos contatos com o Fora, pois isso traz o gosto pela própria destruição e pela construção de novos limites.

Sabemos, pois, que não há uma Psicologia, mas várias maneiras de trabalhar, pensar e intervir no cotidiano. Apesar de suas múltiplas facetas, não raras vezes, ficamos grudados a determinados jeitos de intervenção, como se fossem os únicos possíveis. Nesse sentido, propor a flexibilização psi envolve a composição de novas práticas, que possam ser inventadas, de acordo com as novas demandas do contemporâneo. Então, ao invés de imitar as formas já existentes de trabalho, podemos diluir a forma atual e transformá-la em outra, ou, ainda, provocar o derretimento do contorno atual, para que dele nasçam novos desdobramentos e outros jeitos de atuação psi.

Portanto, podemos ter um olhar sobre o sujeito que se constrói a cada novo encontro. Além disso, também temos a chance de repensar o movimento da própria Psicologia, enquanto tentativa de maquinação de novas dobras e atuações. Assim, temos a possibilidade de criar novos modos de trabalhar em saúde, no sentido de transitarmos entre aquilo que sabemos e a nossa ignorância, o que pode garantir uma base conceitual e, concomitantemente, uma criação mais envolvente para a sua prática. Às vezes, também somos capazes de abrir os nossos discursos, pelo meio, para que dessa rachadura nasçam novos vincos para a intervenção. Não se trata, pois, de uma invenção aleatória.

Segundo Nietzsche (1888/1995), é possível alegrar-se, frente à inesgotabilidade no sacrifício de seus mais elevados tipos. A isso o autor denomina dionisíaco, e tal processo pode se tornar uma ponte para a Psicologia do poeta trágico. Buscamos um modo de trabalhar que se refaz, a partir dos encontros heterogêneos e das contaminações sentidas. $E$, do mesmo modo, atentamos para uma prática psi que não é condizente com os valores do contemporâneo, já que os questiona e os reinventa. Portanto, ao invés de reproduzir uma necessidade de imediatez e gosto pela felicidade e juventude plenas, o poeta trágico, ao experimentar os fazeres da Psicologia, propõe que o sofrer faz parte da vida, assim como a transformação, o contato, o gozo, a busca pela autonomia e pela irreverência.

Dessa maneira, o corpo psi pode acionar dispositivos de vida, e manter, em si, a fome pela diferenciação. É interessante impulsionar os conceitos a dançarem, para que novas demandas sejam acionadas, a partir das necessidades do cotidiano. Desde sempre, é possível ao homem, mesmo o que não dança, promover certas piruetas em sua existência, brincando com sua capacidade de se entregar ao Fora, ao novo, ao caos e ao informe, tal como Dionísio. Ele recebe, porém, as influências de Apolo, de um modo sutil, ardiloso, já que também deseja a definição dos seus limites. $O$ sujeito pode se entregar, pois ele mantém seu eixo e busca o próprio desequilíbrio.É possível investir nos encontros entre Apolo e Dionísio, entre controle e subversão, entre forma e informe. 
Ora, esse não seria, também, o intuito da Psicologia? Isto é, não agüentar mais as formas cristalizadas, as homogeneizações, os controles sobre os corpos, para poder ir além, para fazer girar com toda a forma que impede a potência do corpo? Poderia a própria Psicologia não agüentar mais suas durezas, seus impasses, seus controles, para se arriscar nas intensidades de novas intervenções, novas posturas, novas relações com o mundo? Então, ativar tal potência significa dar movimento às práticas psi, fazendo-as girarem, bambolearem, saltarem, rastejarem, encontrarem novas expressões e significações no contexto da produção de conhecimento que prima pela saúde. Saúde essa que, não raras vezes, parece meio amorfa, parada, quieta, estática. Portanto, é possível não agüentar mais a padronização das intervenções e das produções de saber em Psicologia, a fim de promover certos giros e reviravoltas nos discursos psi. E é quando nos entregamos às possibilidades de transitarmos entre Apolo e Dionísio, entre as certezas e os riscos, que podemos ativar nossas possibilidades de não agüentar mais.

Nossos saberes podem acionar os próprios limites, no momento em que nos damos conta de que somos rodeados por um non sense, um não saber, que envolve aquilo em que tínhamos segurança. Com isso, temos a chance de aprender a nos deliciar com a própria diluição, no sentido de nos apropriarmos do desmanche de ações descontextualizadas ou desprovidas de sabor. Procuramos, pois, novas demandas em saúde, com um olhar mais abrangente sobre o sujeito, não apenas ao que ele é, mas àquilo que ele pode se tornar.

Assim, se o corpo sem órgãos implica um corpo intensivo e roubado de suas certezas, podemos visualizar isso nos saberes em saúde. O corpo psi também pode experimentar novas intensidades, quando ele é capaz de se deparar com os próprios vazios e instaurar algum tipo de esburacamento em seus saberes. A Psicologia tem a possibilidade de transitar entre o equilíbrio e o desequilíbrio, entre a forma e o informe, ao compor novos enredos para as suas práticas e descobertas. As intervenções podem se arriscar a se lançar no imprevisto de novas possibilidades, ao experimentarem novos olhares e novas sensibilidades para com o sujeito. O psicólogo, roubado de si, esvaziado de suas certezas, pode se lançar em novos encontros, ao abrir o próprio corpo para o mundo que o afeta e o convida a dançar. Quando o corpo psi não agüenta mais a própria configuração, ele pode acionar outros acessos ao mundo, para fazer, de tal encontro, uma prática de novas territorialidades em saúde. 


\title{
The body meets Apolo and Dionísio: powers and fragilities
}

\begin{abstract}
We intend to discuss the body that can't stand anymore and we want to think about its relationship with aesthetics. First, we think about the Apollonian-Dionysian art dimension, as referred by Nietzsche. In this manner, Apollo sends us to the beauty of shapes and dance techniques, while Dionysus brings the meaning of drunkenness, risk and intensity. Contemporary dance is made from entwining both, increasing the potential of the paradoxes of the body. In this meaning, the body that can not stand anymore expresses a power of the body, a capacity for not standing old shapes and it may produce new changes. Ítalo Calvino discusses literature as a way to get new expressions. Thus, the writing body may do not stand anymore the old words, in order to create new meanings and new languages. Finally, we talk about whether the psi practices are searching for not standing anymore its own hardness, the old truths, the same doings, in order to create new interventions and studying new knowledge.
\end{abstract}

Keywords: Body. Art. Aesthetics. Awareness.

\section{Le corp rencontre Apolo et Dionísio: puissance et fragilité}

Résumé: Nous avons l'intention de problematiser le corps épuisé et son rapport avec l'esthétique. D'abord, nous pensons à la dimension de l'art apollinienne-dionysique selon Nietzsche. De cette manière, Apolo nous renvoie à la beauté des formes et à la technique que dans la danse, alors que Dionisio apporte la signification de l'ivresse, du risque et de l'intensité. La danse contemporaine est faite à partir de l'enlacement des deux, augmentant, ainsi, le potentiel des paradoxes du corps. De ce fait, l'épuisé exprime la puissance d'un corps, da capacité de ne plus supporter les vieilles formes et celle de produire des changements. Ítalo Calvino pense à la littérature comme une manière d'obtenir de nouvelles expressions. Alors, le corps d'écriture peut ne plus supporter les vieux mots, pour créer de nouvelles significations et de nouvelles langues. A la fin, nous parlons des dures pratiques psi que ne supportent plus leurs rigidités, leurs vieilles vérités, les mêmes pratiques de toujours, dans le but de créer de nouvelles interventions et de découvrir de nouvelles.

Mots-clés: Corp. Art. Estetica. Conocimiento. 


\section{El cuerpo encuentra Apolo y Dioniso: potencias y debilidades}

Resumen: Queremos cuestionar el cuerpo que no soporta más y sus relaciones con la estética. En primer lugar, pensamos la dimensión apolíneodionisíaca del Arte, como Nietzsche. Por lo tanto, Apolo nos retrotrae a las formas bellas, la técnica en la danza, mientras que Dioniso significa la embriaguez, los riesgos y las intensidades. La danza contemporánea viene de los vínculos entre ellos, la alimentación de las paradojas del cuerpo.En ese sentido, no soportar más expresa un poder del cuerpo, una capacidad para no soportar más las viejas formas y producir nuevos cambios. Italo Calvino piensa la literatura como la composición de nuevas expresividades. Entonces, el cuerpo que escribe puede no tolerar más las antiguas palabras para crear nuevos significados y nuevos lenguajes. Por último, hablamos de cómo las prácticas psi son la búsqueda para no tolerar más su propia dureza, las viejas verdades, los mismos haceres, para componer nuevas intervenciones y los nuevos conocimientos.

Palabras-clave: Cuerpo. Arte. Estetica. Connaissances.

\section{Referências}

Calvino, I. (1990). Seis propostas para o próximo milênio (I. Barroso, trad.). São Paulo: Companhia das Letras.

Deleuze, G. (1996, septiembre). El agotado. Confines, 3, 99-105.

Deleuze, G., \& Guattari, F. (1996). Mil platôs: capitalismo e esquizofrenia (Vol. 3, A. Guerra Neto, trad.). Rio de Janeiro: Ed. 34.

Deleuze, G., \& Guattari, F. (1997). Mil platôs: capitalismo e esquizofrenia (Vol. 4, S. Rolnik, trad.). Rio de Janeiro: Ed. 34.

Gil, J. (2001). Movimento total: o corpo e a dança (M. S. Pereira, trad.). Lisboa: Relógio D'Água.

Gil, J. (2002). O corpo paradoxal. In D. Lins \& S. Gadelha (Orgs.), Nietzsche e Deleuze: que pode o corpo (pp. 131-147). Fortaleza: Relume Dumará.

Kastrup, V. (2007). O funcionamento da atenção no trabalho do cartógrafo. Psicologia \& Sociedade, 19(1), 15-22.

Lapoujade, D. (2002). O corpo que não agüenta mais. In D. Lins \& S. Gadelha (Orgs.), Nietzsche e Deleuze: que pode o corpo (pp. 81-90). Fortaleza: Relume Dumará.

Nietzsche, F. (1992). Onascimento da tragédia, ou Helenismo e pessimismo (J.Guinsburg, trad). São Paulo: Companhia das Letras. (Trabalho original publicado em 1872)

Nietzsche, F. (1995). Ecce homo: como alguém se torna o que é (P. C. Souza, trad.). São Paulo: Companhia das Letras. (Trabalho original publicado em 1888) 
Vilene Moehlecke, Psicóloga, Mestre em Psicologia Social e Institucional, Doutoranda do Programa de Pós-Graduação em Informática na Educação e Membro do Grupo de Estudos "Corpo, Arte e Clínica: modos de trabalhar, modos de subjetivar" da Universidade Federal do Rio Grande do Sul. Professora do curso de Psicologia da UNIVATES - Lajeado, RS. Endereço para correspondência: Rua Osvaldo Aranha, 110 B. CEP 93010-040, São Leopoldo, RS. Endereço eletrônico: piruta7@yahoo.com

Tania Mara Galli Fonseca, Professora Orientadora do Programa de Pós-Graduação em Psicologia Social e Institucional, Professora Orientadora do Doutorado em Informática na Educação e Coordenadora do Grupo de Estudos “Corpo, Arte e Clínica: modos de trabalhar, modos de subjetivar" da Universidade Federal do Rio Grande do Sul. Endereço para correspondência: Rua Campos Sales, 262, CEP 90480-030, Porto Alegre, RS.Endereço eletrônico:tfonseca@via-rs.net

Recebido em: 20/08/2007

Aceito em: 24/03/2008 